\title{
Incorporating ICT Tools in an Active Engagement Strategy-based Classroom to Promote Learning Awareness and Self-monitoring
}

\author{
Ang Chooi Kean ${ }^{1}$, Mohamed Amin Embi $^{2}$ \& Melor Md Yunus ${ }^{2}$ \\ ${ }^{1}$ Institute of Teacher Education International Languages Campus, Kuala Lumpur, Malaysia \\ ${ }^{2}$ Faculty of Education, Universiti Kebangsaan Malaysia, Bangi, Malaysia \\ Correspondence: Ang Chooi Kean, Institute of Teacher Education International Languages Campus, Lembah \\ Pantai, 59200 Kuala Lumpur, Malaysia. Tel: 60-322-847-525. E-mail: ackean05@gmail.com
}

Received: April 13, 2012 Accepted: April 18, 2012 Online Published: June 25, 2012

doi:10.5539/ies.v5n4p139 URL: http://dx.doi.org/10.5539/ies.v5n4p139

\begin{abstract}
The paper examines the influence of incorporating information and communication technology (ICT) tools to help learners to promote learning awareness and self-monitoring skills. An open-ended online questionnaire survey was administered to 15 course participants at the conclusion of the course. The data were analysed on the basis of the percentage of responses according to the influence of ICT tools from the perspectives of the two above-mentioned aspects. The responses from the questionnaire were used to support and triangulate the findings. In addition, reflection reports submitted by all the participants were examined to determine the participants' perceptions of the influence of ICT tools on their own learning throughout the course. In general, the findings showed encouraging results in both learning awareness and self-monitoring skills. According to the findings, individual differences in terms of personality traits and ICT knowledge determined the preference for ICT tools, regardless of the specific pedagogical purposes for incorporating these tools. In the future, we aim to use peer learning techniques to develop peer encouragement and motivation among learners.
\end{abstract}

Keywords: ICT tools, learning awareness, self-monitoring, Japanese language classroom

\section{Introduction}

\subsection{Overview}

The use of information and communication technology (ICT) in the field of education is both a focus of study in itself (technology education) and constitutes a medium of support for learning and teaching (educational technology). This paper deals with the latter use. Rieber and Welliver (1989) defined educational technology as a process involving 'a systematic approach to identifying instructional problems and then designing, developing, implementing, and evaluating instructional solutions' (p. 22, as cited in Newhouse, 2002). They argue that 'in order for the full potential of educational technology to be realized, it must be viewed more as a process rather than just the implementation of educational tools' (p. 22, as cited in Newhouse, 2002). Therefore, the process of educational technology begins with the identification of an educational problem and not with the existence of a technology. In other words, the starting point should be well-supported beliefs about learning and then arriving at solutions that are consistent with these beliefs. In this study, specified ICT tools were incorporated as part of the learning process in an intensive oral Japanese language preparatory course for beginners; this was viewed as a solution and support for learning. Specific ICT tools were chosen so as to optimize the limited 12-week course period by providing the participants with 'real learning' opportunities outside the classroom; these tools were used to further enhance participants' active engagement strategy as the learners engaged themselves in performing their learning tasks using the given ICT tools.

Research has shown there to be positive changes in learning through the use of ICT tools (for example, Bayraktar, 2000-2001; Korte \& Hüsing, 2007; Kozma, 2003, as cited in Ilomäki, 2008); however, the content, direction, and depth of the change remain issues for investigation and discussion. As such, this study attempts to examine the 'change' in specific areas of the participants' learning awareness and self-monitoring skills through the incorporation of ICT tools.

\subsection{Problem Statement}

In line with the Ministry of Education's internationalization programme, the Japanese language in-service 
teacher training programme for secondary schools began in September 2005 with the first cohort of the 12-Week Preparatory Japanese Language Course. This was followed up with the first cohort of One-Year Teaching of Japanese as a Foreign Language Course (TJFL) in 2006. Upon successful completion of both courses under the programme, the 'converted' teachers were reposted to both day schools and fully residential schools offering Japanese as a study subject. Despite the intensiveness and concentration of the two courses, with 840 credit hours (12-Week Course: 300 hours; 1-Year Course: 540 hours), oral communicative competency remains a major issue (JFKL, 2010). In other words, at the end of the programme, the level of proficiency of most course participants remained at a lower intermediate level. Based on the researcher's observations and final reports for the first cycle of a 5-year implementation plan (IPG KBA, Annual Reports of TJFL Course 2006-2010), the problems could be divided into two main categories. The first category involves the choice of instructional materials in the programme (especially in the 12-Week Preparatory Course), and the second category concerns the instructional methods that might have resulted in the lack of 'real learning' throughout the programme. In this study, we deal with the effort and initiative of the researcher, who was also the instructor, in charge of speaking skills in overcoming the problem mentioned in the latter category. In addition, as noted by Ang and Mohamed Amin (2010), because the programme is so intensive in terms of training duration, it is indeed important and necessary to promote learner-centeredness and inculcate self-directedness in the course participants in order to produce independent learners that can monitor their own learning during and after the programme. Hence, this study specifically examines the effort involved with incorporating ICT into active engagement strategies in the oral classroom to promote learning awareness and self-monitoring skills among the participants in the 12-Week Preparatory Course of the current Cohort 6 intake which began in mid-August 2011.

\subsection{Related Literature}

1) What is active engagement?

According to Lorain (n.d.), when students are actively engaged in their learning, they are processing and retaining information and using higher order thinking. When teachers design activities that promote active engagement, they are reinforcing student learning, keeping students interested and on task and making learning relevant and fun. Ang and Mohamed Amin (2011) noted that teaching which emphasizes active engagement helps students process and retain information. It leads to self-questioning, deeper thinking, and problem solving. Engagement strategies like repetition, trial and error, and posing questions move the brain into active and constructive learning. Such activities can lead to higher student achievement.

Olson (n.d.) listed down six components of explicit instruction in active engagement strategies: (1) setting the stage, (2) explaining to students what to do, (3) modelling what to do for students, (4) guided practice, (5) independent practice, and (6) closure/assessment. This list displays the development of the learning process from the initial stage of introducing the learning goals until the final stage of assessment of the achieved goals. In this study, the specified ICT tools were incorporated into component 5 (independent practice), where the participants carried out the assigned learning tasks themselves, either in groups, pairs, or individually, based on the nature of the task.

\section{2) Why use ICT tools?}

As discussed above, technology is developed to efficiently solve problems that arise because of human need (Newhouse, 2002). In other words, if there is no problem to solve, then technology will not be developed and/or adopted. Applying this principle to educational technology would mean that educators should create and adopt technologies that address educational problems, of which there are many. However, educators will not adopt a technology for which there is no perceived need or productivity gain. Newhouse (2002) asserts that educators should create and adopt technologies that address educational problems and/or improve productivity. In addition, according to Trucano (2005), there is widespread belief that the use of ICTs can and will empower teachers and learners, transforming the teaching and learning processes from being highly teacher-dominated to being student-centred; this transformation will then result in increased learning gains for students, creating and allowing opportunities for learners to develop their creativity, problem-solving abilities, informational reasoning skills, communication skills, and other higher-order thinking skills. However, there are currently very limited, unequivocally compelling data to support this belief.

In their qualitative case study approach to examining the impetus for change, Wong et al. (2008) identified four different types of ICT implementation strategies from a sample of eight schools in Hong Kong and Singapore: the technologically driven type, the pedagogically driven type, the balanced type, and the uncoupled type. Wong et al. characterised the schools that realized changes in classroom practices by ICT-pedagogical innovations. They further asserted that to witness any changes, pedagogical innovations must be rooted in teachers' experiences of 
moving away from a teacher-centred approach to one that is more student-centred. Other studies have also revealed that students must be the knowledge generators and active participants in their own learning, while teachers must only act as facilitators (Means, 1994; Jonassen, Peck \& Wilson, 1999).

\subsection{The Purpose of Study}

This study examines the course participants' perceptions of the influence of the specified ICT tools-(1) audio recordings using mobile phones or MP3 players, (2) multimedia PowerPoint (PPT) presentations with audio recordings, and (3) video recordings uploaded onto YouTube — on their learning awareness and self-monitoring skills. In addition, this study attempts to identify the challenges and hindrances faced by the participants when using these ICT tools.

\section{Methodology}

\subsection{Research Design}

In this descriptive study, we used both quantitative and qualitative data collection methods, including administering an online survey questionnaire and analysing reflection reports. The online survey questionnaire, rated on a 4-point Likert scale ( 1 = highly disagree; 4 = highly agree), was administered to 15 course participants at the conclusion of the course. The questionnaire consisted of 12 statement-based items that were constructed according to the aspects of learning awareness (4 items) and self-monitoring skills. Self-monitoring skills were divided into two sub-categories: organization of learning (4 items) and monitoring of learning (4 items).

\subsection{Instrumentation}

The findings were reported in terms of the number of respondents and percentile. Through open-ended questions, the researchers were able to investigate the participants' views regarding the specific ICT tools used as well as identify the problems or challenges the participants faced. In addition, reflection reports submitted by all the participants were examined to further gauge the participants' perceptions of the influence of ICT tools on their own learning throughout the duration of the course. Finally, all the qualitative data obtained from the open-ended items in the questionnaire and analyses of reflection reports were triangulated with the participants' responses from the quantitative data obtained from the survey questionnaire.

\subsection{Procedures}

The quantitative data collected from the questionnaire were analysed on the basis of learning awareness and self-monitoring skills, which comprised organization and monitoring of learning. In addition, the participants were asked to rate the influence on these aspects with respect to three types of tools-audio recordings using mobile phones or MP3 players (speaking journal), PPT presentations with audio recordings (graphics narration), and video recordings uploaded onto YouTube (role play collection)—on a 4-point Likert scale: 1: Little influence, 2: Some influence, 3: Moderate influence, and 4: Big influence. Qualitative data obtained from the open-ended items in the questionnaire and reflection reports were examined and analysed on the basis of the 'grounded theory' of categorization.

\section{Findings and Discussion}

\subsection{Perceptions of Learning Awareness}

Table 1. Participants' Perceptions of Statements Pertaining to Learning Awareness

\begin{tabular}{|c|c|c|c|c|c|}
\hline Aspect & Item & $\begin{array}{l}1 \\
\text { Strongly } \\
\text { Disagree } \\
(\%)\end{array}$ & 2 & 3 & $\begin{array}{l}4 \\
\text { Strongly } \\
\text { Agree }\end{array}$ \\
\hline $\begin{array}{l}\text { Learning } \\
\text { Awareness }\end{array}$ & $\begin{array}{l}\text { The ICT tools employed helped me to } \\
\text { identify my learning strengths. } \\
\text { The ICT tools employed helped me to } \\
\text { identify my learning weaknesses. } \\
\text { The ICT tools employed helped me to } \\
\text { identify the important areas in my learning. } \\
\text { The ICT tools employed helped me to } \\
\text { identify my immediate learning needs. }\end{array}$ & $\begin{array}{l}0 \\
(0 \%) \\
0 \\
(0 \%) \\
0 \\
(0 \%) \\
0 \\
(0 \%) \\
\end{array}$ & $\begin{array}{l}1 \\
(7 \%) \\
2 \\
(13 \%) \\
1 \\
(7 \%) \\
1 \\
(7 \%)\end{array}$ & $\begin{array}{l}7 \\
(47 \%) \\
7 \\
(47 \%) \\
9 \\
(60 \%) \\
9 \\
(60 \%) \\
\end{array}$ & $\begin{array}{l}7 \\
(47 \%) \\
6 \\
(40 \%) \\
5 \\
(33 \%) \\
5 \\
(33 \%) \\
\end{array}$ \\
\hline
\end{tabular}

$\mathrm{n}=15$

Overall, as indicated in Table 1, most of the participants (87\%-94\%) agreed with the 12 statements pertaining to the influence of ICT tools on learning awareness. However, one participant (7\%) (R9) disagreed with all these 
statements.

As shown in Table 1, two respondents (R9 and R14) disagreed with the following statement: 'The ICT tools employed helped me to identify my learning weaknesses'.

Table 2. Rating of the Degree of Influence on Learning Awareness

\begin{tabular}{llllc}
\hline Degree of Influence/ ICT Tool & $\begin{array}{l}\text { Little } \\
\text { Influence }\end{array}$ & $\begin{array}{l}\text { Some } \\
\text { Influence }\end{array}$ & $\begin{array}{l}\text { Moderate } \\
\text { Influence }\end{array}$ & $\begin{array}{l}\text { Big } \\
\text { Influence }\end{array}$ \\
\hline $\begin{array}{l}\text { Audio Recordings Using Mobile } \\
\text { Phones, etc. (Speaking Journal) }\end{array}$ & $0 \%$ & $13 \%$ & $53 \%$ & $33 \%$ \\
$\begin{array}{l}\text { Audio Recordings Using PPT } \\
\text { Presentations (Graphics Narration) }\end{array}$ & $0 \%$ & $20 \%$ & $53 \%$ & $27 \%$ \\
$\begin{array}{l}\text { Video Creations Uploaded Onto } \\
\text { Youtube (Role Play Collection) }\end{array}$ & $0 \%$ & $13 \%$ & $33 \%$ & $53 \%$ \\
\hline
\end{tabular}

As shown in Table 2, all the participants (100\%) felt that the ICT tools influenced-to some extent or to a major extent-their learning awareness. By incorporating audio recordings when developing their speaking journals, more than half the participants (53\%) perceived a moderate influence on all aspects of learning awareness skills. Similarly, by incorporating audio recordings in PPT presentations when creating their graphics-based narrations, $53 \%$ of the participants perceived a moderate degree of influence on their learning awareness. In relation to the incorporation of video recordings uploaded onto YouTube in developing role play video collections, 53\% of the participants perceived a big influence on their learning awareness.

The qualitative data from the open-ended items in the questionnaire and the reflection reports also indicated that the incorporation of ICT tools enhanced learning awareness among the participants. Two representative excerpts which indicated awareness in terms of the realization of personal improvements and mistakes are cited below:

Video creation at the beginning was very difficult as I was relying on the text to be able to act (out the role play). Often, I have to redo the video when I forget my lines. Towards the last task, I felt more at ease, even though there might have been mistakes here and there. [R1]

I really liked video creation and role play. It did seem difficult and really challenging in the beginning, but later, it did help me a lot in improving my pronunciation, communication skills, and my comfort when speaking Japanese. The best part is that I can watch my own video. From there, I can see myself (the way people see me, physically) and my expressions when speaking Japanese. Most importantly, I can see my own mistakes. [R7] 


\subsection{Perceptions of Self-monitoring Skills}

Table 3. Participants’ Perceptions of Statements Pertaining to Self-monitoring Skills

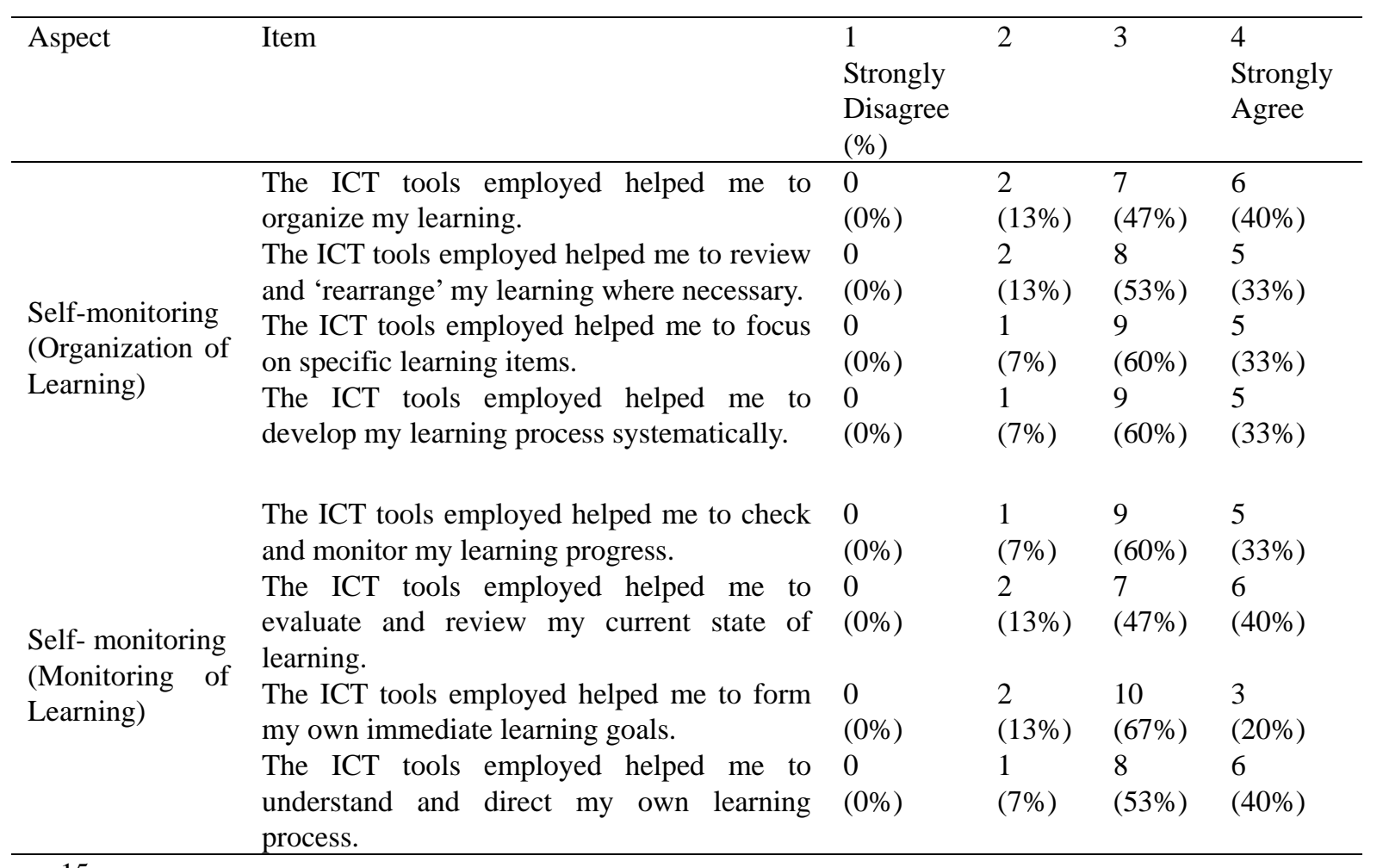

$\mathrm{n}=15$

Overall, as indicated in Table 3, most of the participants (87\%-94\%) agreed with the 12 statements pertaining to the influence of ICT tools on self-monitoring skills, which comprised organization and monitoring of learning. However, one participant (7\%) (R9) disagreed with all these statements.

Two respondents (R9 and R14) disagreed with the following three statements: 'The ICT tools employed helped me to organize my learning', 'The ICT tools employed helped me to review and "rearrange” my learning where necessary', and 'The ICT tools employed helped me to evaluate and review my current state of learning'. In addition, two students (R9 and R10) disagreed with the statement, 'The ICT tools employed helped me to form my own immediate learning goals'.

Table 4. Rating of the Degree of Influence on Self-monitoring (Organization of Learning)

\begin{tabular}{|c|c|c|c|c|}
\hline $\begin{array}{l}\text { Degree of Influence/ } \\
\text { ICT Tool }\end{array}$ & $\begin{array}{l}\text { Little } \\
\text { Influence }\end{array}$ & $\begin{array}{l}\text { Some } \\
\text { Influence }\end{array}$ & $\begin{array}{l}\text { Moderate } \\
\text { Influence }\end{array}$ & $\begin{array}{l}\text { Big } \\
\text { Influence }\end{array}$ \\
\hline $\begin{array}{l}\text { Audio Recordings Using Mobile } \\
\text { Phones, etc. (Speaking Journal) }\end{array}$ & $0 \%$ & $20 \%$ & $53 \%$ & $27 \%$ \\
\hline $\begin{array}{l}\text { Audio Recordings Using PPT } \\
\text { Presentations (Graphics Narration) }\end{array}$ & $0 \%$ & $20 \%$ & $60 \%$ & $20 \%$ \\
\hline $\begin{array}{l}\text { Video Creations Uploaded Onto } \\
\text { Youtube (Role Play Collection) }\end{array}$ & $0 \%$ & $13 \%$ & $40 \%$ & $47 \%$ \\
\hline
\end{tabular}


Table 5. Rating of the Degree of Influence on Self-monitoring (Monitoring of Learning)

\begin{tabular}{llllc}
\hline Degree of Influence/ ICT Tool & $\begin{array}{l}\text { Little } \\
\text { Influence }\end{array}$ & $\begin{array}{l}\text { Some } \\
\text { Influence }\end{array}$ & $\begin{array}{l}\text { Moderate } \\
\text { Influence }\end{array}$ & $\begin{array}{l}\text { Big } \\
\text { Influence }\end{array}$ \\
\hline $\begin{array}{l}\text { Audio Recordings Using Mobile } \\
\text { Phones, etc. (Speaking Journal) }\end{array}$ & $0 \%$ & $20 \%$ & $53 \%$ & $27 \%$ \\
$\begin{array}{l}\text { Audio Recordings Using PPT } \\
\text { Presentations (Graphics Narration) }\end{array}$ & $0 \%$ & $13 \%$ & $60 \%$ & $27 \%$ \\
$\begin{array}{l}\text { Video Creations Uploaded Onto } \\
\text { Youtube (Role Play Collection) }\end{array}$ & $0 \%$ & $20 \%$ & $47 \%$ & $33 \%$ \\
\hline
\end{tabular}

On the other hand, it is interesting to note that neither R10 nor R14 refuted the influence of any of the ICT tools on self-monitoring skills in terms of organization and monitoring of learning, as seen in Tables 4 and 5.

Based on Tables 4 and 5, it can be seen that all the participants (100\%) perceived that the ICT tools influenced - to some degree or a large degree-their self-monitoring skills. By incorporating audio recordings using mobile phones or MP3 players when developing their speaking journals, more than half the participants (53\%) perceived there to be a moderate influence on both aspects of self-monitoring skills in their learning. Similarly, by incorporating audio recordings in PPT presentations when creating graphics-based narrations, $60 \%$ of the participants perceived a moderate degree of influence in both organization of learning and monitoring of learning. With regard to the incorporation of video recordings uploaded onto YouTube in developing role play video collections, $47 \%$ of the participants perceived a big influence in terms of their organization of learning, and $47 \%$ perceived a moderate degree of influence on monitoring their learning.

These findings were supported by the qualitative data obtained from open-ended items in the questionnaire (Appendix 1). Generally, the findings from the reflection reports confirmed positive perceptions about the ICT strategies employed. The representative responses below showed that the participants perceived the ICT tools to be beneficial in supporting their learning:

I like the implementation of ICT tools in a lesson because it makes the lesson easier to understand. [R4]

The use of ICT tools really helps me in my learning progress. [R7]

The use of ICT tools is indeed good in helping me to learn Japanese better. [R11]

All the three methods...really influence my learning progress. The methods speed up my learning progress. [R12]

The following is yet another insightful excerpt on the influence of ICT tools on self-monitoring skills and self-evaluation:

For my speaking journal, I do not only practise my speaking; I can also listen to what I say and improve on it. This helps me to monitor my own speaking ability as well as my progress. Most of the time, we do not realize how we sound when we speak. Some people may realize their errors after making the mistakes, but will mostly forget the moment they are done speaking. So, the speaking journal is effective for me to keep track of my speech. I can evaluate what I hear. [R12]

\subsection{Challenges and Hindrances Faced by Participants When Using the Specified ICT Tools}

The qualitative data obtained from the open-ended items provided clear and additional information and insights into the feelings of the respondents, their perceptions, and their opinions and beliefs regarding their learning experiences using the three types of ICT tools. Details of these findings are listed in Appendix 1.

It is interesting to note that there were two formulated categories which indicated a mixture of negative and positive responses in the context of the participants' learning experiences: 'Tiring but enlightening' and 'challenging but interesting'. The three main categories pertaining to hindrances or problems faced were 'time constraints', 'slow Internet speeds', and 'lack of technical knowledge’. 
Some participants experienced frustration due to slow Internet speeds and technical problems, leading to a sense of insecurity in terms of ICT knowledge. The excerpts below exemplify how such feelings of frustration hinder the participants' learning process:

In terms of voice recording, I did not encounter too many problems. However, the process of synchronizing my voice in time with the animation took considerable time, and I feel disappointed that I had to spend more time re-editing my PPT. Besides, the technicalities involved in PPT preparation somehow troubled me. [R1]

I enjoyed preparing my 'kazoku' PPT but grew frustrated when no one I sent the file to could hear the audio, even after countless attempts to fix the problem. [R14]

Contrarily, other participants, even those without high ICT knowledge, gained various skills or changed their perceptions about ICT tools as a consequence of their learning experiences using these tools. Some excerpts are below:

Earlier, I hated using the video camera, let alone be taped to be watched in front of others. Role play changed that for me, I guess. I know that as time goes by, this will be the tool that will have the most impact on me. [R8]

This course was my first experience with using audio recording in PPT. It was very interesting and helped a lot in enhancing my language skills. [R9]

Apart from the audio recordings, PPT has helped my learning a lot, especially when I could display the information I liked in writing. [R10]

\section{Implications and Discussion}

Four implications of this study are identified and discussed along with considerations for future improvements.

\subsection{Personality and Individual Differences}

The findings of the study revealed that there were individual differences in the participants' preferences for particular ICT tools. The following excerpts exemplify two participants' differed preferences with regard to the use of PPT.

(PPT is) not much of a help in language learning. The important part was the audio recording using mobile phones/iPhone. The PPT only taught me technical aspects. [R2]

[I was] more comfortable with the use of PPT while learning. With only 1 slide, I was able to speak a lot. Nevertheless, I hope that learning with these ICT tools will really help me in improving my Japanese language skills. [R10]

Individual differences in terms of personality traits were also significant when it came to participants' preferences for particular ICT tools:

I found that audio recordings using audio recorder is not giving the best effect in my learning. This is because of the noise during the recording and poor handling of the recording tool would affect our pronunciation. The recorded voice then would not be clearly heard. [R4]

I liked this process of learning audio recording using PPT presentation because instead of just the voice recordings, it has also graphics. So, here I have two things to focus. If the audio is not very clear, then I could refer to the displayed PPT. [R4]

I liked that the audio recordings using mobile phones as they have indeed helped me greatly in upgrading my learning skills in Japanese language. For instance, I would listen back to my own recordings and then identify the mistakes that I have made in them. [R10]

I felt uneasy when performing the video creation task. Standing in front of the camera caused nervousness which, in turn, caused disappointment as I could not perform well. [R10]

Individual differences in terms of ICT knowledge and attributes have most probably contributed to the finding, mentioned earlier in the text, about participant R9 disagreeing with all the 12 statements. In fact, this probability is supported by R9's views, reported below:

I am very weak in using ICT. Nevertheless, I shall try my best to improve and overcome my weaknesses. [R9]

In a nutshell, in order for ICT tools to be effective in learning, instructors need to take into consideration individual differences among learners. It is interesting to note that in this study, despite being briefed at the 
beginning of the course, some participants seemed to be more 'concerned' with 'how to use the ICT tools' than the instructional purpose of using the particular tools. Therefore, as a future improvement, it is necessary to emphasize the specific pedagogical purposes of incorporating ICT tools in order to better orientate and prepare learners to be less 'sceptical' and be more 'open-minded' about using particular ICT tools that they might personally not prefer or be accustomed to; in other words, learners should always bear in mind the educational purposes behind using the tools. One way of preparing learners is for the instructor to carry out a quick survey regarding ICT knowledge or ICT tool preferences prior to the commencement of lessons; instructors should also provide the necessary support to learners, where necessary. As aptly asserted by MacNeill, Cavanagh, and Silcox (2005), successful classroom pedagogy requires that instructors understand how their students learn and have the autonomy to design, implement, and assess educational activities that meet the needs of individual and all students.

\subsection{Peer Involvement}

The findings of this study reveal that in addition to the successful use of ICT tools, their influence on the intended learning outcomes in practice is somehow affected by peer involvement among learners; this was especially the case because the present study focused on oral communication skills. This finding can be indicated in the following excerpts:

However, nothing is always perfect. The speaking journal has its cons. If we send an audio mail to our friend, it takes time to get a reply. Therefore, the heat of a (face-to-face) conversation cannot be maintained through the speaking journal. [R12]

I love doing role plays although they are the hardest. Earlier, I hated using the video camera, let alone be taped to be watched in front of others. Role play changed that for me, I guess. I know that as time goes by, this will be the tool that will have the most impact on me. Not only that, but I also realize that team members play a major role in succeeding at the video camera task. Coordination should be good in every aspect. I feel that when planning the video shoot, we helped each other and identified each other's weaknesses and supported them so that they were equally good. Research was carried out and new vocabulary was put to the test. It was tiring but still fun learning. [R8]

Peer involvement is an important factor in the implementation of active engagement strategies which underlie peer learning. Peer learning is defined as 'the acquisition of knowledge and skill through active helping and supporting among status equals or matched companions' (Wang \& Chen, 2008, p.19). In other words, in this active engagement strategy-based practice of incorporating ICT tools, it was important for the learners to have a partner or an audience that would be mutually engaged in the learning process. In addition, through this peer learning, participants would be able to overcome the above-mentioned individual differences in terms of ICT knowledge and attributes. Based on the processes of peer learning, peer assessment, and peer feedback, learners with different learning styles can achieve the same level of ICT skills and learning progress (Wang \& Chen, 2008). In addition, Wang and Chen (2008) examined the perspectives of compensation and enhancement; that is, when learning strategies are suited to learners' strong learning styles, those learners' performance and motivation will be enhanced, and when learning strategies are suited to learners' weak learning styles, those learners' ICT skills will be compensated.

The following excerpt indicates the 'difficulties' or 'reservations' faced as well as the 'benefits' gained by a participant, from the perspective of being involved or engaged as a peer in the learning process:

I think all the tools are great when integrated in the speaking lessons, but sometimes, when I have to spend too much time on listening to and commenting on other people's work, I feel uneasy because I have to listen hard and try to correct them. I really don't want to make insincere comments, and I don't like to correct other people as I also don't have enough knowledge to correct other people yet. But, I can still learn a lot from watching other people as I can improve my own language. [R6]

This quote implies the importance of preparing and facilitating learners, practically, which involves peer learning. The reason for this 'restriction' is probably that the participant was not accustomed to such a practice before. However, as noted by Amelia, Mohamed Amin, and Rosseni (2009) in their study on collaborative learning community, 'The role of peers is also important in ensuring everybody participates in the learning process' (p.125).

\subsection{Time-related Concerns}

Lack of ICT knowledge can result in participants facing technical problems, which in turn, can cost them more time than really needed for the tasks. This is probably why some participants highlighted the fact that they had 
time constraints when completing tasks:

PowerPoint is a great way to express ideas during speeches; nevertheless, it is time consuming when we need to create the PowerPoint (presentation) from scratch. [R6]

However, some participants seemed to be 'over-concerned' or even 'distracted' by the short duration of the course, which might have led them to have doubts about the out-of-the classroom learning tasks assigned. Consequently, they became 'sceptical' about the use of ICT tools to promote learning, despite being aware of the positive influence of these tools on their learning progress. The following excerpt is representative of this view:

The methods speed up my learning progress, but I also have to admit that time is a factor that can affect the effectiveness of the methods. [R12]

Another possible contributing factor is the time-management skills of the participants. Some of the study participants seemed to have faced difficulties in managing time for the assigned tasks:

I used the audio recording for 'jikoshoukai'. I made mistakes in it and should have made other recordings to correct these, but I never got around to it. [R14]

It would be helpful if sensei were to give us a certain target for the speaking journal, e.g. three 'jikoshoukai' recordings over the course of a month. So, by the third month, we would be recording our three speeches and therefore would be able to see how much we have improved. [R14]

I suggest that the timetable have an ICT section so that students can concentrate on the task that is given. [R3]

\subsection{ICT Facilities and Internet Connection}

One of the common constraints with regard to the use ICT tools is the availability of related facilities. In fact, prior to the implementation of this project, the instructor had taken into consideration this factor by confirming the availability and use of audio and video recording devices, personal computers, and broadband Internet access for participants. However, some participants did not reconfirm the availability of certain resources, which posed a hindrance when performing some learning tasks. Slow Internet speed was yet another drawback, especially when uploading video files onto YouTube. Moreover, since YouTube was not accessible via the institution's server, the participants were forced to use their own broadband Internet connections, which were too slow to accommodate the upload and download of video files. This issue is exemplified in the following excerpt:

However, certain limitations such as...lack of recording (video/audio) devices can affect the system. Another problem I faced is that the speed of my server was very low, and uploading/downloading tasks took up a lot of time, distracting me from my goals. Overall, ICT outcomes are very interesting. I wish we have advanced technology in IPBA that we can use anytime to serve that purpose. [R15]

\section{Conclusion}

In conclusion, it can be said that the incorporation of the specified ICT tools in this active engagement strategy-based practice undoubtedly and positively influenced learning awareness and self-monitoring skills among the participants. Through incorporating the ICT tools, the participants were actively engaged in performing the out-of-class learning tasks, which indicates that the use of ICT tools was successful as a pedagogical solution initiated by the instructor to optimize learning outside the classroom and provide opportunities for 'real learning'. It is essential to uphold or maintain these successful learning outcomes and adopt necessary steps to overcome problems such as individual differences in terms of ICT knowledge and attributes; this is especially important for application in the subsequent program in order to ensure the effectiveness of the practice and that it has a real impact. Future work should deal with efforts in ensuring 'successful learners' from among the 'less-committed' or 'sceptical' participants, using peer learning techniques to develop peer encouragement and motivation.

\section{References}

Amelia Abdullah, Mohamed Amin Embi, \& Rosseni Din. (2009). Development of a collaborative learning community through computer-mediated communication. In Mohamed Amin Embi. (Ed.) Computer-mediated communication: Pedagogical implications of Malaysian research findings (pp. 128-141). Shah Alam: Karisma Publications.

Ang, C.K., \& Mohamed Amin Embi. (2010). Promoting learning awareness and self-monitoring through learning portfolio development among Japanese language learners. European Journal of Educational 
Studies, 2(3), 293-304. Retrieved from http://ozelacademy.com/EJES_v2n3_12.pdf

Ang, C.K., \& Mohamed Amin Embi. (2011). Using active engagement strategy to promote learning awareness and self-monitoring. International Journal of Learning and Development, 1(1), 91-109. Retrieved from http://www.macrothink.org/journal/index.php/ijld/article/view/1105/856

Ilomäki, L. (2008). The effects of ICT on school: Teachers' and students' perspectives. Retrieved from http://www.doria.fi/bitstream/handle/10024/42311/B314.pdf?sequence=3

Institut Pendidikan Guru Kampus Bahasa Antarabangsa (IPG KBA). Annual reports of One-Year Teaching of Japanese as Foreign Language (TJFL) Course 2006-2010.

Japan Foundation Kuala Lumpur (JFKL). (2010). Malaysian teachers struggling with Japanese language: The Japan Foundation supports trainings for teachers of secondary education. Retrieved from http://www.jpf.go.jp/world/en/archives/1008.html

Jonassen, D. H., Peck, K. L., \& Wilson, B. G. (1999). Learning with technology: A Constructivist perspective. Upper Saddle River, New Jersey: Merrill/Prentice Hall.

Lorain, Peter. (n.d.) Teaching that emphasizes active engagement. Improving learning for middle school students. Retrieved from http://www.nea.org/tools/16708.htm

Macneill, N., Cavanagh, R.F., \& Silcox, S. (2005). Pedagogic leadership: Refocusing on learning and teaching. International Electronic Journal For Leadership In Learning, 9. Retrieved from http://www.ucalgary.ca/iejll/vol9/silcox

Means, B. (1994). Introduction: Using technology to advance educational goals. In B. Means (Ed.), Technology and education reform. San Francisco: Jossey-Bass Publishers.

Newhouse, C.P. (2002). Literature Review: The impact of ICT on learning and teaching, Perth: Specialist Educational Services. Retrieved from http://www.det.wa.edu.au/education/cmis/eval/downloads/pd/impactreview.pdf

Nor Izah Mohd Salleh, \& Norazah Mohd.Nordin. (2008). Pengintegrasian ICT dalam pengajaran dan pembelajaran: Isu dan cabaran. [Integration of ICT in teaching and learning: Issues and challenges]. In Norazah Mohd Nordin, \& Mohamed Amin Embi (Eds). Pengintegrasian ICT dalam pendidikan penyelidikan, amalan dan aplikasi. [Integration of ICT in educational researches, practice and application] (pp.1-9). Shah Alam: Karisma Publications.

Olson, C. (n.d.) Active engagement strategies. In Shasta County Office of Education, Active engagement strategies for each explocit instruction component. Retrieved from http://www.shastacoe.org/page.cfm?p=3232

Trucano, M. (2005). Knowledge maps: ICTs in education. Washington, DC: infoDev /World Bank.

Wang, L.C., \& Chen, M.P. (2008). Enhancing ICT skills learning through peer learning: Perspectives of learning style and gender. International Journal of Education and Information Technologies, 1(2), 18-23.

Wong, E. M. L., Li, S. S. C., Choi, T.H., \& Lee, T. N. (2008). Insights into innovative classroom practices with ICT: Identifying the impetus for change. Educational Technology \& Society, 11(1), 248-265. 


\section{Appendix}

Appendix 1. Categorization of Open-Ended Items of the Questionnaire

Category Sample Extract of Responses

Fun and Enjoyment

Sense of Achievement

Useful as Learning

Supports

Learning Awareness

Monitoring of learning process

Promotion of Peer Cooperation and Ties

Building of Confidence

Self-Evaluation

Challenging but interesting

Tiring but Enlightening

Time Constraint

Slow Internet Speed Connection

Lack of Technical Knowledge ...it is a great enjoy of learning.

Indeed helpful in upgrading my communication skills.

PPT helps me to deliver my speech confidently without losing my point of speech because $i$ have the guides from each slide.

The visual /graphic guided the speaking \& overcame stammering

ICT is useful in enhancing my learning awareness....

...this is actually acting as a mirror. It helps us to keep track of our ability as well as learning progress. I can figure out which part of sentence structure that needs to pay attention to.

ICT is useful in enhancing .....and self-monitoring...

Despite some degree of pronunciation errors and lack of fluency at times, I could see obvious improvement in speaking Japanese language

Improved ties with peers and helped in overcoming shortcomings \& filling the learning gap among peers through the group discussions during preparation.

Guided aid provided by the slides boosted confidence in speaking

The best part is, I can watch my own video. From there, I can see myself (just the way people see me physically) and also my expression when using the Japanese language. Most important, i can see my own mistakes by myself.

I love doing role plays although it is the hardest of all.

Research was carried out and new vocabulary was put to test. Tiring but still fun learning.

.... I couldn't catch up to the pace of the upcoming task. I felt ICT do help us if we can afford the time.

is the speed of my server is very low thus uploading/downloading task consuming lot of time and distract my focus.

Technical problem, however, is a factor that may cause more production time. To compile the video or to upload the video, both need lots of time. 